may have been poor and shabby but he had become that much-loved figure, the family doctor. The physician was no longer lampooned as a mercenary buffoon, because he had become a powerful symbol of medical science. While the poor doctor was still very poor and the rich very rich, the profession as a whole had risen in status and public esteem by the end of the nineteenth century.

\title{
Medicine and Empire
}

\author{
MILTON LEWIS*
}

\author{
Mark Harrison, Public health in British \\ India: Anglo-Indian preventive medicine, \\ 1859-1914, Cambridge History of Medicine, \\ Cambridge University Press, 1994, pp. xviii, \\ 324 , illus., $£ 45.00$ (hardback 0-521-44127-7), \\ $£ 19.95$ (paperback 0-521-46688-1).
}

The history of public health is emerging as a major concern of contemporary historians of medicine. Of course, we had decades ago histories of public health in the United Kingdom, the home of the nineteenth-century sanitary idea. These were usually reliable accounts of legislative and administrative developments but were not very sensitive to the social, political, economic and cultural context of public health history. Then, there appeared George Rosen's classic, $A$ history of public health (1958). It was certainly sensitive to context, but it stood for a long time in splendid isolation. Recently, we have seen established a European Network for the History of Public Health, with the promise of regular conferences and plentiful publications and, no doubt, the emergence of a European perspective on the history of public health transcending national boundaries yet alive to the variety of national experiences. We also have the very useful comparative history, The history of public health and the modern state (1994) edited by Dorothy Porter. Countries historically on the periphery of the European public health movement, whether "new" countries of European settlement like the United States and Australia or countries of ancient, non-European culture briefly under European control or influence like India or China, have been much less well served by historians. A national history of public health in the United States, John Duffy's The sanitarians, appeared only in 1990 . A national history of public health in Australia has yet to be written. Kerrie Macpherson promoted study of China by exploring the origins of public health in Shanghai in $A$ wilderness of marshes (1987). The work of Radhika Ramasubban on "imperial health" and that of David Arnold on epidemic disease have opened up inquiry into the history of Indian public health. Now, the history of public health in British India up to 1914 has been documented and critically assessed by Mark Harrison. His study is both a contribution to the history of medicine and health in India itself and to the history of "imperial medicine". As a contribution to the former, it can stand in its own right. But knowledge of the British period is also important to an informed understanding of post-independence health policy, as Roger Jeffery observed in a recent study of the politics of health in modern India. Those critical of imperial rule have long claimed that

*Dr Milton Lewis, University of Sydney 


\section{Essay Reviews}

imperialism lowered Indian living standards and that economic development promoted spread of infectious disease. Where health and medical intervention took place, it was largely for the benefit of Europeans, especially the Army, as Radhika Ramasubban has argued. Defenders of empire have pointed out that British rule brought public order, economic modernization, famine relief and scientific medicine, but that indigenous poverty and cultural opposition critically constrained British policy. Neither side has attempted to look in adequate detail at the impact of the health measures introduced in the sixty years following the passing of the Government of India Act, 1858. Harrison has certainly done this.

Harrison makes clear at the outset that his is a thematic, not a narrative, history of public health. It differs from existing studies, in explaining the limited effect of medical interventions, by its stress on the importance of political relations with sections of the Indian population, the involvement of Indians in policy-making at the municipal level (from 1882), the conflict of views within the administration and among doctors, the significance of constraints like restricted local revenues, and the limited role of preventive medicine in the consolidation of British control.

\section{The Indian Medical Service}

The author aims in his first chapter to place the IMS in its relevant social and political context, arguing IMS doctors enjoyed less occupational control and social influence than their colleagues at "home", partly because of the Indian Government's subordination of medical to military and political considerations and in part because of the low status of the IMS compared with the Army and the ICS. The IMS was beset by conservatism and "status anxiety" which worked against public health innovation. In his second chapter, he discusses the nature of tropical hygiene, pointing out that even in the 1880 s, with the discovery of the typhoid bacterium and the malaria protozoon, most IMS doctors continued to focus on the role of weather, dirt and contaminated food and water in the causation of these diseases. He makes the important point that tropical hygiene shaped, and was shaped by, changing attitudes to things Indian. Under the spur of mounting mortality and post-Mutiny anxieties, Indian medicine and cultural practices ceased to be valued. Indians came to be seen as degenerate and an integral part of the sanitary problem.

In chapter 3, he discusses the bases of public health policy and argues the 1857 Mutiny gave rise to ongoing concern about the health of troops so the focus of sanitary endeavours was the military cantonment and, only secondarily, the indigenous population. Initiatives affecting the latter were further limited by fear of offending popular sensibilities, financial stringency, logistics, and the opposition of Indian urban élites. Again, the author shows how political, social and cultural considerations influenced public health policy. This argument is taken further in chapter 4 , where he shows how, in the face of epidemic cholera, the Indian Government resisted pressure from foreign governments (concerned about international spread) and the military for more custodial measures because it was concerned about the mass unrest likely to result. Moreover, it selected medical officers to investigate cholera whose views on the aetiology of the disease were compatible with a comparatively inactive policy approach. Even in the 1890 s, when the internationally agreed view of the centrality of the bacillus was finally accepted, it was integrated into the earlier causal framework.

The interplay between internal and external policy issues relating to quarantine and the annual pilgrimage of Muslims to Mecca and Medina is charted in chapter 5 . The Indian Government shared with Britain the wish to see free passage of shipping maintained, but the former was firmly opposed to quarantine of pilgrims because it would anger Muslims in India. Similarly, it was reluctant to respond to international pressure for better sanitation on pilgrim ships because this would antagonize poor Muslims struggling to meet the cost of 


\section{Essay Reviews}

pilgrimage obligations. Britain's occupation of Egypt alienated Muslims everywhere and it displeased France, which increased its support for quarantine proposals.

\section{Medical developments}

Harrison goes on to deal with a number of medical developments in 1896-1914, a period which began with the arrival of epidemic plague and ended with increasing recruitment of Indians into the IMS and the promotion of research in tropical medicine. The Indian Plague Commission (from 1898) recommended establishment of a network of laboratories but the Indian Government only supported research where this suited broader policy, as was the case with malaria research, where much international prestige was gained from promoting investigation of this widespread tropical disease.

In chapter 7, an account is given of the impact of local self-government on public health progress from the 1880s. Progress was generally slow, although some municipal areas like Bombay achieved a good deal by the 1900s. The author concludes that regional variations in expenditure on sanitary measures reflected not only differences in wealth but also the self-interest of property-owning municipal commissioners and Indian cultural resistance to sanitary reform, although many Western-educated Indians were enthusiastic sanitarians. Chapter 8 continues the study of the politics of public health at the municipal level, focusing on Calcutta, the centre of government and the most prosperous city of late-nineteenth-century British India. The plague crisis and the appointment of Curzon as viceroy in 1898 enabled European control of municipal government to be re-established under the banner of sanitary reform and slum clearance. But the European administration pursued financial self-interest as assiduously as had the Indian rate-payers and rentier class who had previously dominated local government, so death rates remained high.

\section{Conclusions}

At the close of his study, Harrison makes some important points, and in doing so challenges the conclusions of other scholars who have contributed to the history of medicine in India or, more generally, to the history of imperial medicine: first, the view of Radhika Ramasubban and others that the priority given to the health of Europeans and the military arose from low valuation of the health of the indigenous population is too limited because it ignores the capacity of Indian élites to influence policy, differences within the administration, and the practical obstacle of mass poverty; second, medicine as a tool of empire was less influential than Philip Curtin and others have suggested, and morbidity remained serious in the Army until this century, while agricultural development proceeded with little attention to medical effects; third, official attitudes to public health were affected by the competition between paternalism and liberalism, and the latter envisaged gradual reform with avoidance of politically dangerous measures which would antagonize Indian opinion; and fourth, financial constraints, popular suspicion, and political imperatives all restricted sanitary progress, but government could have assisted struggling municipal authorities, and local élites could have provided more leadership; yet, arguably, co-operation was impossible in a colonial situation where the cultural distance between rulers and ruled was so great, and where government, in the ultimate, always gave preference to the needs of the rulers.

Mark Harrison's study adds substantially to our historical knowledge of public health and medicine in British India. It also valuably contributes to the debate about the role of medicine in European empires in ways I have indicated above. The basic strength of the study, as is the case with all good social history of medicine, lies in its contextual emphasis-in showing how the interplay between public health and medicine, on the one hand, and political, economic, social and cultural factors, on the other, shaped the development of public health in India in the late nineteenth and early twentieth centuries. 